\title{
Gender Role in Mediating Capital Relations and Information Technology Investment with SME Financial Performance During the Covid-19 Pandemic
}

\author{
Riskin Hidayat ${ }^{1}$, Hetty Muniroh ${ }^{2}$ \\ \{rieskqien@yahoo.co.id ${ }^{1}$ \} \\ Management Department, STIE YPPI Rembang, Indonesia ${ }^{1}$ \\ Accounting Department, STIE YPPI Rembang, Indonesia ${ }^{2}$
}

\begin{abstract}
This study aims to test the role of gender in mediating capital relations and information technology investment with the performance of SMEs during the covid-19 pandemic. SMEs are also affected by the covid-19 pandemic, so the financial performance of SMEs is disrupted. SME problems during the covid-19 pandemic are related to capital and the demands of the use of information technology so that SMEs need to invest in information technology. Besides, gender roles are very important in managing SME finances to improve their financial performance. Thus, this study incorporates gender to mediate the gap between capital and information technology investment and the financial performance of SMEs. The samples in this study are SMEs in Rembang Regency. Sampling techniques using cluster sampling and obtained samples as many as 142 SMEs. The results showed that capital has a positive effect insignificant on the financial performance of SMEs, while information technology investment has a significant positive effect on the financial performance of SMEs. This study proves that gender can mediate the relationship between capital and information technology investment with the performance of SMEs during the covid-19 pandemic.
\end{abstract}

Keywords: Gender, capital, information technology investment, financial performance

\section{Introduction}

Capital is a major factor in a business. Capital owned by the company will affect the performance of a company and the sustainability of its business. Capital obtained by a company, its use will depend heavily on its business needs. But in general, the capital owned by the company will be used for the company's operations and also for investment. The company's capital structure will affect financial performance [1]. So is the importance of capital for small and medium enterprises (SMEs). SME capital usually comes from its capital, from its SME owners. This is because SMEs have limitations in accessing external sources of funds, such as debt to banks [2]. This is similar to research found by Gul [3] capital from debt negatively affects performance in SMEs in Pakistan.

On the contrary, the results of the research found by [4], [5], and [6] that the capital owned by SMEs has a positive effect on performance. Capital has a positive influence on the performance of SMEs perhaps because SMEs can manage their capital well. The capital is used effectively and efficiently so that its performance becomes increased. Another possibility is that 
the capital owned by SMEs is used for efficient operations and proper investment so that it can achieve high performance.

Another important factor that affects the performance of SMEs is an investment. In the financial function of the company, investment is one of the important factors that must be taken into account by the company [7], because with the investment made, the company can develop its business so that it can achieve high performance. High company performance is a goal that must be achieved by every company for the sustainability of its business. One of the investments that need to be made by SMEs is an investment in information technology, in this case, SMEs can invest in the procurement of websites, laptops, smartphones, or desktop computers.

In today's digital era, investment in information technology is very important to support the performance of SMEs. Investment in information technology can be used for promotion or marketing or financial recording of business transactions. Especially in the current Covid-19 pandemic, where most business transactions use digital. This is by data from Kominfo that in 2017 internet users in Indonesia of 132 million active internet users and social media users amounted to 106 million. Of the 106 million social media users, YouTube users by $49 \%$, Facebook by $48 \%$, Instagram by $39 \%$, Twitter by $38 \%$, WhatsApp by $38 \%$, and Google by $38 \%$ [8]. Judging from its domicile, $78.5 \%$ of all Internet users in Indonesia live in western Indonesia.

The results of research [9] [10] that investment in information and communication technology has a positive effect on the performance of SMEs. Studies as [11], [12], and [13] found that information technology has a positive effect on the performance of SMEs. Research [14] investment in R\&D negatively affects performance, but investment in information technology has a positive effect on the performance of SMEs. Different results indicated by the [15] found there was a 60\% decrease in investment in start-up SMEs in China in the first quarter of 2020 compared to the first quarter of 2019.

The Covid-19 pandemic has a profound impact on the economy globally, including in Indonesia. At the time of the Covid-19 pandemic in Indonesia starting in March 2020 greatly impacted SMEs. According to the Ministry of SMEs and Cooperatives that until October 2020 SMEs were affected by the Covid-19 pandemic as much as $90 \%$ [16]. The impact is very felt by SMEs in Indonesia, including SMEs in Rembang Regency. To overcome the impact of the Covid-19 pandemic, the government is implementing the National Economic Recovery (PEN) policy by providing direct cash assistance to SMEs so that SMEs can rise again.

However, the results of research [17] show that women SME actors in Pathumthani province in Thailand as a key factor in the recovery of SMEs performance after the flood disaster in 2011, meaning that women SME actors can improve the performance of MSMEs. The results of the study are interesting for us to include gender, in this case, women SME actors become intervening variables in overcoming the gap between capital and investment in information technology and the performance of SMEs. The results are also supported by the findings [18] and [19] that SME entrepreneurial women can improve their business performance.

Data from [20] the role of self-employed women in urban areas is $20.95 \%$ and in rural areas by $18.47 \%$; while men are $18.54 \%$ for urban areas and $18.63 \%$ for rural areas. For women who are self-employed to be assisted by out-of-work/underpaid workers in urban areas by $10.99 \%$ and in rural areas by $16.85 \%$; while the male in urban areas by $9.34 \%$ and rural areas by $25.92 \%$. The data shows that the gender role of women is entrepreneurial, especially in urban areas are still better than men. Based on the gap in research results and phenomena as described above, this study aims to test the role of gender in mediating the influence of capital and investment on information technology on SME performance during the Covid-19 Pandemic. 


\section{Method}

The population in this study is SMEs in Rembang regency. SMEs were chosen because they have a significant contribution to the economy, but are currently most affected by the Covid-19 pandemic. Sampling in this study using cluster sampling was done by dividing the population into groups or parts. Multiple clusters are then randomly selected. The data items in the selected cluster are sampled.

Data collection techniques in this study use survey techniques by distributing questionnaires directly to SME managers (owners) who are eligible for sampling. SME population data in Rembang regency as much as 586, from the population, will be sampled as many as 200 companies. The number has met the adequacy of the sample statistically. [21] a good number of samples for research with a minimum multivariate analysis method of 130 . The results of the distribution of questionnaires to 200 SMEs respondents in Rembang Regency can be seen in Table 1.

Table 1. Results of Questionnaire Dissemination

\begin{tabular}{lll}
\hline \multicolumn{1}{c}{ Information } & Amount & Percentage \\
\hline Distributed questionnaire & 200 & $100 \%$ \\
Non-returned questionnaire & $(42)$ & $(21 \%)$ \\
Questionnaires were returned & 158 & $79 \%$ \\
The questionnaire is incomplete and cannot be analyzed & $(16)$ & $(8 \%)$ \\
\hline Total questionnaire analyzed & 142 & $71 \%$ \\
\hline
\end{tabular}

The variables in this study consisted of independent variables, mediation variables, and dependent variables. The independent variables in this study were capital measured by the amount of working capital used and investment in information technology measured using a Likert scale of 1 to 5, ranging from highly unavailable to highly available with the number of 10 statement items. The mediation variable in this study is gender, namely if women SME actors are rated 1 and if male SME actors are rated 2, it is because this research will look at the role and involvement of entrepreneurial women in SMEs. Dependent variables in this study are financial performance as measured by the income earned by SMEs. Statistical testing using path analysis with WarpPLS application software with the following equation:

$$
\begin{gathered}
\text { Gender }=\alpha_{1}+\beta_{1} \text { Capital }+\beta_{2} \text { InvesTI }+\mathrm{e}_{1} \\
\text { Perform }=\alpha_{2}+\beta_{3} \text { Capital }+\beta_{4} \text { InvesTI }+\beta_{5} \text { Gender }+e_{2}
\end{gathered}
$$

\section{Result and discussion}

This study uses path analysis to test the role of mediation variables, namely gender in mediating the influence of capital and investment on information technology on the financial performance of SMEs. Direct effect test results can be seen in Table 2. 
Table 2. Direct Effect Test Results

\begin{tabular}{lll}
\hline Path & Coefficient & P Value \\
\hline Capital $\square$ Perform & 0.025 & 0.375 \\
InvesTI $\square$ Perform & 0.303 & $<0.001^{* * *}$ \\
Capital $\square$ Gender & 0.122 & $0.074^{*}$ \\
InvesTI $\square$ Gender & 0.163 & $0.023^{* *}$ \\
Gender $\square$ Perform & 0.136 & 0.051 \\
\hline Desip
\end{tabular}

Description: * significant at $10 \%, * *$ significant at $5 \%$ and $* * *$ significant at $1 \%$

Capital as an independent variable measured by capital issued by SMEs; InvesTI is an investment in information technology as an independent variable measured on a Likert scale of 1-5, ranging from highly unavailable to highly available with a total of 10 statement items; Gender is a mediation variable measured by 1 for women and 2 for men, and Perform is the financial performance of SMEs as measured by the assets obtained by SMEs.

Table 2 shows that capital has an insignificant positive effect on the financial performance of SMEs. This means that there is no direct influence of capital on the financial performance of SMEs. These findings show that SMEs in Rembang Regency is also affected by the Covid-19 pandemic. This is most likely because most SMEs do not produce to the maximum due to the decrease in the purchasing power of the community. Another reason is because of the policy of limiting the opening of stalls, offices, tourist attractions, and others so that SMEs can not sell their products to the maximum which is due to the decrease in SME income.

However, along with the easing of the policy of restricting business premises, offices, and tourist attractions, as well as the presence of direct cash assistance for SMEs from the government, the condition of SMEs has begun to rise again. It is also confirmed when the inclusion of gender variables, in this case, is female entrepreneurship as a mediation variable, it turns out that the results of this study found there is an indirect influence of capital on the financial performance of SMEs in Rembang Regency. This means that gender, namely entrepreneurial women have an important role in raising the financial performance of SMEs in Rembang Regency. This is because women tend to be abler to manage financially than men. During the Covid-19 pandemic, entrepreneurial women can manage their capital well for their business interests.

SME business capital must be managed properly by SMEs to rise from the uncertain economic conditions due to the impact of the Covid-19 pandemic and for the sustainability of SME businesses. In the Covid-19 pandemic, it requires the role of female entrepreneurs to manage SME capital to rise from the decline in performance, especially in utilizing capital from the government in the form of direct cash assistance. Sources of business capital can come from internal, namely own capital or paid-up capital and retained earnings, can also come from external sources, namely debt in banks, bond debt, and venture capital [23]. However, most SMEs tend to use internal sources of capital, namely their capital, due to limited access of SMEs to financial institutions such as banks and others. In theory, the implementation of SMEs in the use of capital sources tends to use pecking order theory [24].

The findings of this study are consistent with the results of study [4], [5] and [6] which found that capital has a direct effect on the performance of SMEs. These results are also reinforced by research [17], [18] and [19] found that gender can mediate the effect of capital on the performance of SMEs. The results of this study show that gender, in this case, is that entrepreneurial women have a significant role in mediating the influence of capital on the financial performance of SMEs. 
Table 2 also shows that investment in information technology has a significant positive effect on the financial performance of SMEs. This means that there is a direct influence of investment in information technology on the performance of SMEs in Rembang Regency. This happens because SMEs in Rembang Regency have used information technology, especially on social media. Investment in information technology during the Covid-19 pandemic is very important because people are restricted from directly intervening. It requires business transactions to use information or digital technology. So it is appropriate if SMEs in managing their business during the Covid-19 pandemic invest in information technology, meaning that SMEs buy and use information technology such as smartphones, websites, laptops, and personal computers to market and promote their products through social media such as WhatsApp, Instagram, the Facebook, marketplace, and others, which can expand the reach of the market and can gain new customers from outside the city, perhaps even abroad so that the performance of SMEs can increase.

Investment in information technology in addition to being used for marketing activities can also be used to record business financial transactions because currently there are many applications to make financial statements downloaded for free. The findings are by investment behavior in neoclassical theory [25]. The theory explains that it is the exogenous variable that determines the company's investment, namely sales. When sales increase, then followed by investment decisions, vice versa when sales fall the company's investment will also fall. This is because sales are the main determinant that affects investment.

If SMEs can be appropriately and effectively invested, it will be able to improve performance, which means it can improve the welfare of owners. Information technology used by SMEs according to [11] can significantly improve the financial performance of SMEs, especially the use of social media [26]. The findings of this study are the following results of research [9], [10], and [14] found that investment in information technology can improve the performance of SMEs.

The findings of this study also show that gender, namely SME entrepreneurship women in Rembang regency can mediate the influence of investment on information technology on the financial performance of SMEs. This means that there is an indirect influence of investment in information technology on the financial performance of SMEs. This shows the very important role of entrepreneurial women in improving the performance of SMEs during the Covid-19 pandemic. The role of women today is proving capable of competing with men in the economy. Not only at the family level, but also at the national and even global level. Not a few women manage their businesses, by establishing micro, small and medium enterprises (MSMEs). With its spirit, creativity, innovation, and ability, women can become strong entrepreneurs in doing business. According to [27] and [28] women's success in entrepreneurship is also supported by their advantages, among others: conscientious, diligent, serious, painstaking, tenacious, honest, patient, strong will, high dedication, as well as discipline in administration and managing finances.

The results of [12] that the adoption of information technology by SMEs in India had a significant positive effect on the performance of SMEs in Bangladesh. The East Java also found that gender, namely entrepreneurial women have used information technology in the form of ecommerce for competitive strategies to improve the performance of SMEs. The findings of this study also show that investment in information technology by SME entrepreneurs in Rembang Regency can improve its financial performance, especially during the Covid-19 pandemic. So that these findings can show that gender, namely entrepreneurial women can mediate the influence of investment on information technology on the financial performance of SMEs. For 
full gender role models in mediating capital and investment in information technology to the financial performance of SMEs can be seen in Figure 1.

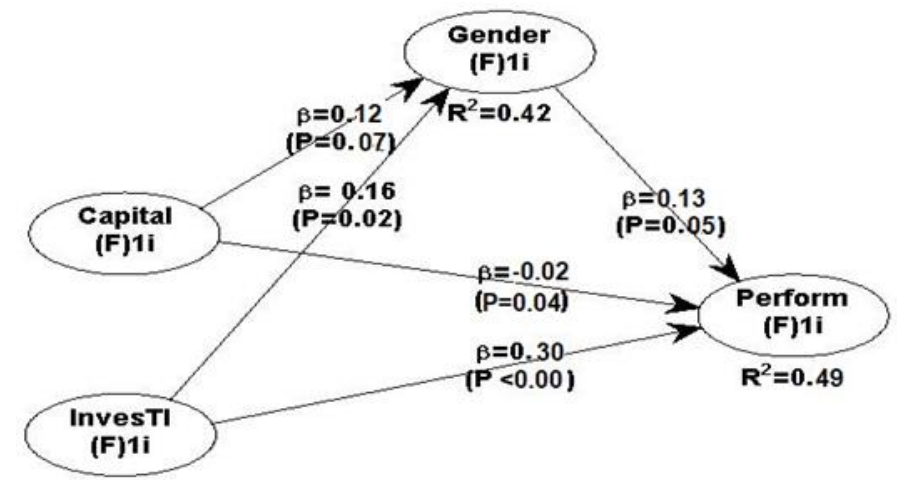

Fig. 1. Full Model Research

\section{Conclusion}

From the description above, the conclusions of this study are: first, during the Covid-19 pandemic, capital did not have a significant effect on the financial performance of SMEs, this was because there were not many SMEs producing due to government restrictions and decreased purchasing power. Second, investment in information technology has a significant effect on the financial performance of SMEs. This means that during the Covid-19 pandemic it is important for SMEs to invest in information technology in the form of smartphones, laptops, and personal computers because it is prohibited to confuse directly between people, and as a solution, they must take advantage of information technology, both for marketing through social media, websites or marketplaces, sales. or other business transactions. Third, gender can mediate the effect of capital and information technology investment on the financial performance of SMEs. These findings prove that women entrepreneurs have a very important role in improving the financial performance of SMEs.

\section{Acknowledgement}

The author would like to thank STIE YPPI Rembang for funding and allowing the author to take part in the 2nd Borobudur International Symposium 2020.

\section{References}

[1] E. F. Brigham, and M. C. Ehrhardt, Fundamentals of Financial Management: Cengage Learning, 2012.

[2] M. Irjayanti and A. M. Azis, "Barrier factors and potential solutions for Indonesian SMEs," Procedia economics and finance, vol. 4, pp. 3-12, 2012. 
[3] S. Gul, M. B. Khan, S. Rahman, M. T. Khan, M. Khan, and W. Khan, "Working capital management and performance of SME sector," European Journal of Business and Management, vol. 5, pp. 6068, 2013.

[4] N. P. M. Dewi and T. Utari, "Pengaruh modal, tingkat pendidikan dan teknologi terhadap pendapatan usaha mikro kecil dan menengah (UMKM) di Kawasan Imam Bonjol Denpasar Barat," E-Jurnal Ekonomi Pembangunan Universitas Udayana, vol. 3, p. 44496, 2014.

[5] M. Nizar, "Pengaruh Sumber Daya Manusia, Permodalan dan Pemasaran Terhadap Kinerja Usaha Kecil dan Menengah Sari Apel di Kecamatan Tutur," Iqtishoduna: Jurnal Ekonomi Islam, vol. 7, pp. 51-69, 2018.

[6] S. Baños-Caballero, P. J. García-Teruel, and P. Martínez-Solano, "Financing of working capital requirement, financial flexibility and SME performance," Journal of Business Economics and Management, vol. 17, pp. 1189-1204, 2016.

[7] E. F. Fama, "The Empirical Relationship between the Dividend and Investment Decisions of Firm," The American Economic Review, vol. 64, pp. 304-318, 1974.

[8] E. Mahardika and G. GUSTI AJI, "Implementasi Komunikasi Pemasaran Digital dalam Promosi Pariwisata (Studi Kasus Pada Kota Wisata Batu)," Commercium, vol. 1, 2018.

[9] A. O. Gomes, S. T. Alves, and J. T. Silva, "Effects of investment in information and communication technologies on the productivity of courts in Brazil," Government Information Quarterly, vol. 35, pp. 480-490, 2018/09/01/2018.

[10] A. Mohamad, Y. Zainuddin, N. Alam, and G. Kendall, "Does decentralized decision-making increase company performance through its Information Technology infrastructure investment?," International Journal of Accounting Information Systems, vol. 27, pp. 1-15, 2017/11/01/ 2017.

[11] R. Eller, P. Alford, A. Kallmünzer, and M. Peters, "Antecedents, consequences, and challenges of small and medium-sized enterprise digitalization," Journal of Business Research, vol. 112, pp. 119$127,2020$.

[12] M. S. Azam, "Diffusion of ICT and SME performance," in E-Services Adoption: Processes by Firms in Developing Nations, ed: Emerald Group Publishing Limited, 2015.

[13] R. Hidayat and S. Alliyah, "Pengembangan Sistem Pengambilan Keputusan Yang Berkualitas Bagi UKM Melalui Penerapan Sistem Akuntansi Manajemen Berbasis Teknologi Informasi," Fokus Ekonomi: Jurnal Ilmiah Ekonomi, vol. 8, 2013.

[14] I. Estrada and J. Q. Dong, "Learning from experience? Technological investments and the impact of coopetition experience on firm profitability," Long Range Planning, vol. 53, p. 101866, 2020/02/01/ 2020.

[15] R. Brown and A. Rocha, "Entrepreneurial uncertainty during the Covid-19 crisis: Mapping the temporal dynamics of entrepreneurial finance," Journal of Business Venturing Insights, vol. 14, p. e00174, 2020/11/01/2020.

[16] A. Kristianus, "Kemenkop UKM: 90\% UMKM Terdampak Pandemi Covid-19," in Investor daily Indonesia, ed. https://investor.id/business/kemenkop-ukm-90-umkm-terdampak-pandemi-covid19, 2020.

[17] S. Pathak and I. E. Emah, "Gendered approach towards disaster recovery: Experiences from 2011 floods in Pathumthani province, Thailand," International Journal of Disaster Risk Reduction, vol. 24, pp. 129-134, 2017/09/01/2017.

[18] D. H. B. Welsh, E. Kaciak, and R. Shamah, "Determinants of women entrepreneurs' firm performance in a hostile environment," Journal of Business Research, vol. 88, pp. 481-491, 2018/07/01/ 2018.

[19] E. D. Sumarwati and A. N. Rachman, "Analisis Faktor-Faktor Yang Mempengaruhi Kinerja UMKM (Studi Kasus UMKM Perempuan Di Kabupaten Sukoharjo)," INCONTECSS| ISBN: 978-62392318-1-1, pp. 242-250, 2019.

[20] Badan Pusat Statistik, Profil Perempuan Indonesia 2019. Jakarta: Kementrian Pemberdayaan Perempuan dan Perlindungan Anak, 2020.

[21] J. Hair, J.F., R.E Anderson, R.L. Tatham dan William C. Black Multivariate Data Analysis With Readings, 7th Edition ed. New Jersey: Prentice-Hall, Englewood Cliffs, 2018. 
[22] H. Latan, dan I. Ghozali, Partial Least Squares: Konsep, Metode dan Aplikasi Menggunakan Program WarpPLS 5.0, Third Edition ed. Semarang: Badan Penerbit Universitas Diponegoro, 2017.

[23] E. F. Brigham and M. C. Ehrhardt, Financial management: Theory \& practice: Cengage Learning, 2013.

[24] S. C. Myers, "The capital structure puzzle," The journal of finance, vol. 39, pp. 574-592, 1984.

[25] D. W. Jorgenson, "Econometric Studies of Investment Behavior: A Survey," Journal of Economic Literature, vol. 9, pp. 1111-1147, 1971.

[26] R. Odoom, T. Anning-Dorson, and G. Acheampong, "Antecedents of social media usage and performance benefits in small-and-medium-sized enterprises (SMEs)," Journal of Enterprise Information Management, 2017.

[27] S. Febriani, "Peran Wanita Dalam Pengembangan Usaha Kecil dan Menengah Di Kota Padang," Padang: Jurnal Manajemen dan Kewirausahaan, vol. 3, pp. 10-20, 2012.

H. E. Indiworo, "Peran perempuan dalam meningkatkan kinerja UMKM," EQUILIBRIA PENDIDIKAN: Jurnal Ilmiah Pendidikan Ekonomi, vol. 1, pp. 40-58, 2016.

[28] E. Kurniawati, "Pengaruh Kondisi Sosial Terhadap Perilaku Pengambilan Keputusan "Perempuan" Pemilik UMKM Jawa Timur Untuk Mengadopsi E-Commerce," Jurnal Sosiologi Pendidikan Humanis, vol. 4, pp. 94-102, 2020 